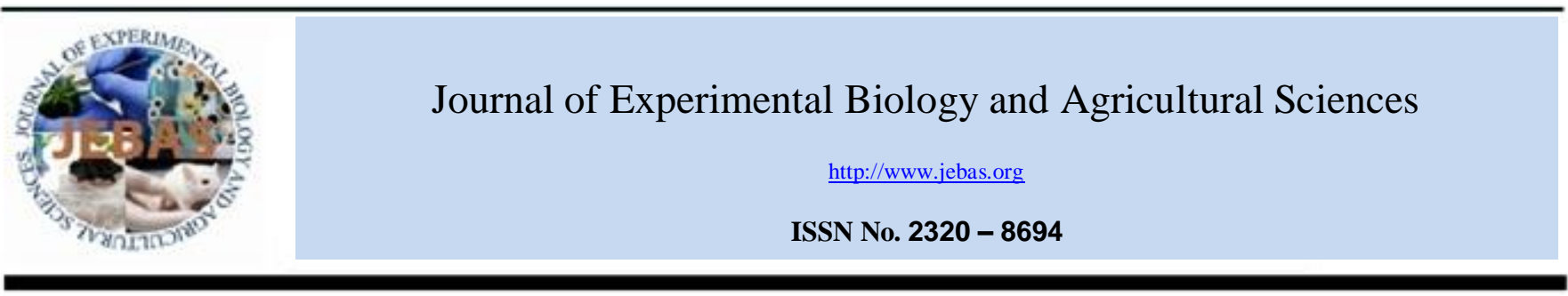

\title{
EFFECT OF VERMICOMPOST AND TRIPLE SUPERPHOSPHATE ON YIELD OF CORN (Zea mays L) IN BEHBAHAN
}

\section{Sayfallah Amyanpoori ${ }^{1, *}$, Maysam Ovassi ${ }^{1}$ and Ebrahim fatahinejad ${ }^{2}$}

${ }^{1}$ Departments of Agronomy Sciences, Varamin Branch, Islamic Azad University, aramin, Iran
${ }^{2}$ Departments of Soil Sciences, Behbahan Branch, Islamic Azad University, Behbahan, Iran

Received - January 10, 2015; Revision - February 14, 2015; Accepted - November 18, 2015

Available Online - December 15, 2015

DOI: http://dx.doi.org/10.18006/2015.3(6).494.499
KEYWORDS
Corn
Vermicompost
Triple superphosphate
Growth parameters
Yield components

\begin{abstract}
This study was conducted to investigate the effects of vermicompost and chemical fertilizers on corn yield. Study was carried out at Gomez village in Behbahan, Iran in cropping season of 2013. The experiment was design in factorial completely randomized block design with four replications. Two doses of vermicompost viz $5000 \& 10000 \mathrm{~kg} \mathrm{ha}^{-1}$ and three level of triple superphosphate i.e. 50, $75 \&$ $100 \%$ were used as study factors. Effect of these factors were accessed on chlorophyll content, plant height, harvest index, rows number per cob, cob per plant, 1000 seed weight, grains number in rows and yield. Result of study revealed a positive correlation between the level of selected factors and various growth parameters; increasing in the applied quantity of vermicompost and phosphorus also increased the cholorophyll content, growth, yield and other yield components of the plant.
\end{abstract}

* Corresponding author

E-mail: Amianpory@yahoo.com (Sayfallah Amyanpoori)

Peer review under responsibility of Journal of Experimental Biology and Agricultural Sciences.

Production and Hosting by Horizon Publisher (http://publisher.jebas.org/index.html).

All rights reserved.
All the article published by Journal of Experimental Biology and Agricultural Sciences is licensed under a Creative Commons Attribution-NonCommercial 4.0 International License Based on a work at www.jebas.org.

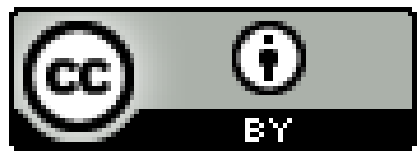




\section{Introduction}

Wheat, rice and maize are the most important cereal crops throughout the world but maize is the most popular due to its high yielding, easy processing, readily digested and less costs than other cereals (Jaliya et al., 2008). It widely used as a major source of carbohydrate in human and livestock diet. Significatory effect of corn in textile and pharmaceutical industries was also well reported hence it is called 'queen of cereal'. In cereals, maize can grow throughout the year mainly due to photo thermo insensitive characteristics. Maize has immense potential in the tropics and its yield reached up to 7.5 $\mathrm{t} /$ ha if the crop is properly managed (Law-Ogbomo \& LawOgbomo, 2009). But unfortunately still crop yields are below 5 $\mathrm{t} / \mathrm{ha}(\mathrm{FAO}, 2007)$ and it caused inadequacy of maize for its numerous usages. Yield differences between temperate and tropical areas have been attributed to low nutrient status especially these soils are deficient to nitrogen, phosphorus and potassium. Resulting of slash and burn farming system associated with bush fallow and excessive leaching of the soil nutrients (Law-Ogbomo \& Law-Ogbomo, 2009) are presently unsustainable due to high population pressure and other human activities which have resulted in reduced fallow period (Steiner, 1991).

Various factors affected the productivity of winter maize; however, the fertilizer management is one of the most important factors that affect the growth and yield of maize (Anonymous, 1979). Low fertility status of tropical soils hindered maize production as maize has a strong exhausting effect on the soil. It was generally observed that maize fail to produce good grain without adequate nutrients (Adediran \& Banjoko, 2003). Inorganic fertilizer exerts strong influence on plant growth, development and yield of maize crop (Predieri et al., 2004). Availability of sufficient nutrients leads to improve cell activities, cell multiplication and enlargement and luxuriant growth (Fashina et al, 2002). Luxuriant growth resulting from fertilizer application leads to larger dry matter production (Obi et al., 2005) owing better utilization of solar radiation and more nutrient (Saeed et al., 2001). Furthermore, substantial depletion of nutrients increased with the cultivation where no NPK fertilizer was applied Adediran \& Banjoko (2003).

Vermicomposting technology involves the bio-conversion of organic waste into vermicasts and vermiwash utilizing earthworms (Jadia \& Fulekar, 2008). These earthworms feed on the waste and their gut act as the bioreactor where the vermicasts are produced (Ansari \& Sukhraj, 2010). These vermicasts are also termed vermicompost and are rich in nitrogen, phosphorous, potassium and micronutrients (Ansari \& Sukhraj, 2010; Palanichamy et al., 2011). Effect of these vermicompost on plant growth is well reported but mostly it used as a main source of nitrogen.
Phosphorus is an essential nutrient as a part of several key plant structural components and worked as catalysis in the conversion of numerous key biochemical reactions in plants. Availability of phosphorus in tropic soils is very low and average $0.6 \% \mathrm{P}$ was reported from these soil. Phosphorus (P) deficiency is a major constraint to agricultural production affecting an area of over 2 billion hectares worldwide (Fairhust et al., 1999). Soil P is classified in two broad group's i.e. organic and inorganic, availability of inorganic $\mathrm{P}$ in acid Alfisols in the tropics can be limited by its adsorption onto $\mathrm{Fe}$ and $\mathrm{Al}$ oxides and by formation of $\mathrm{Fe}$ and $\mathrm{Al}$ phosphate complexes with humic acids (Gerke, 1992).

Phosphorus transformation in soils involves complex microbiological, chemical and biological process. Unlike C and $\mathrm{N}$, phosphorus does not undergo oxidation-reduction reaction in soil but occupies a central position in organic matter decomposition (Zibilske et al., 2002). Plant roots acquire inorganic phosphorus from the soil solution. Immobilization of inorganic $\mathrm{P}$ by microbes and its gradual release via microbial turnover can protect $\mathrm{P}$ from physicochemical adsorption reactions if their release is synchronized with the demand of growing plants and or a subsequent generation of microorganisms (Magid et al., 1996). This study therefore focused on evaluating the effect of individual or combined application of vermicompost and phosphorus on the growth of corn over the time.

\section{Materials and Methods}

This study was conducted under field conditions in 2013 at Behbahan Khozestan, Iran. Behbahan is located in $160 \mathrm{~km}$ south east of Ahwz (50 $12^{\prime} \mathrm{N}, 30^{\circ} 36^{\prime} \mathrm{E}, 320 \mathrm{~m}$ above the sea level). Average annual precipitation study site is $354.2 \mathrm{~mm}$ and average annual temperature is $24^{\circ} \mathrm{C}$. The properties of soil at the test site are listed in Table 1.

The study was conducted in factorial completely randomized block design with four replications. The factors studied were Phosphorus (50,75 and $100 \%)$ and Vermicompost (0, 5 and 10 $\mathrm{t} / \mathrm{ha}$ ) while the plots without phosphorus or vermicompost are treated control. Each treatment was replicated four times. Distance between plant to plant was $75 \mathrm{~cm}$ while the distance between rows plans in each row was $15 \mathrm{~cm}$. Seeds were planted in the month of May, 2013 and irrigated regularly. Thinning was conducted after emergence, when plants were at four leaves stage.

\section{Results and Discussion}

\subsection{Effect of fertilization on chlorophyll content}

Analysis of variance showed that vermicompost and phosphorus had significant effect on chlorophyll content $(\mathrm{p}<$ $0.05)$. 
Table 1 Physio-chemical characteristics of the study area soil.

\begin{tabular}{|c|c|c|c|c|c|c|c|c|c|c|}
\hline Organic carbon (\%) & T.N.V & $\mathrm{K}\left(\mathrm{mg} \mathrm{kg}^{-1}\right)$ & $\mathrm{P}\left(\mathrm{mg} \mathrm{kg}^{-1}\right)$ & $\mathrm{N}(\%)$ & Sand \% & Silt $\%$ & Clay \% & Texture & Ec $\left(\right.$ ds m$\left.^{-1}\right)$ & $\mathrm{Ph}$ \\
\hline 19.14 & 17.5 & 350 & 20.09 & 2.07 & 41 & 29 & 36 & loamy Clay & 5.34 & 8.2 \\
\hline
\end{tabular}

All the data were collected from the department of soil sciences, Behbahan Branch, Islamic Azad University, Behbahan, Iran

Table 2.Mean of squares for cholorophyl content,plant height and yield components in corn.

\begin{tabular}{|c|c|c|c|c|c|c|c|c|c|}
\hline Source of variance & df & $\begin{array}{l}\text { harvest } \\
\text { index }\end{array}$ & T. Chl & $\begin{array}{l}\text { Plant height } \\
(\mathrm{cm})\end{array}$ & $\begin{array}{l}\text { Rows number } \\
\text { per cob }\end{array}$ & Cob per plant & $\begin{array}{c}1000 \text { seed weight } \\
\text { (gr) }\end{array}$ & $\begin{array}{c}\text { Grains number in } \\
\text { rows }\end{array}$ & $\begin{array}{l}\text { Seed yield } \\
\quad(\mathrm{kg})\end{array}$ \\
\hline Vermicompost (A) & 2 & $803.6 *$ & $.0159 *$ & $20043 * *$ & $699.9 *$ & $7.01 *$ & $10001 *$ & 30988.3* & $35883301 * *$ \\
\hline Phosphorus (B) & 3 & $792.6 *$ & $.0131 *$ & $2800.3 *$ & $701.6 *$ & $6.92 *$ & $1889.3^{\mathrm{ns}}$ & $34888.2 *$ & $790042 *$ \\
\hline $\mathrm{A} \times \mathrm{B}$ & 6 & $5800.3 * *$ & $.0141 * *$ & $12888^{* * *}$ & $22881 * *$ & $38.82 * *$ & $14882.9 * *$ & $139002.6 * *$ & $40843221 * *$ \\
\hline Error & 16 & 125.6 & .0022 & 453.6 & 102.4 & 1.45 & 255.6 & 4899.2 & 1245880 \\
\hline $\mathrm{Cv}(\%)$ & & 10.12 & 6.18 & 15.4 & 12.21 & 9.21 & 8.88 & 13.82 & 15.15 \\
\hline
\end{tabular}

${ }^{\mathrm{ns}}$, non Significant, *and ${ }^{* *}$ : Significant difference at $5 \%$ and $1 \%$ level respectively

Table 3 Effect of individual application of various level of vermicompost on Corn yield.

\begin{tabular}{|c|c|c|c|c|c|c|c|c|}
\hline Treatment & & & Mean of $\mathrm{Pz}$ & neters & & & & \\
\hline Vermicompost (t/ ha) & harvest index & T. chl & Plant height $(\mathrm{cm})$ & Rows number per cob & Cob per plant & 1000 seed eight (gr) & Grains number in rows & Seed yiel $(\mathrm{kg})$ \\
\hline 0 & $33.9^{\mathrm{b}}$ & $1.44^{\mathrm{c}}$ & $169.1^{\mathrm{c}}$ & $15.5^{\mathrm{b}}$ & $1.18^{\mathrm{b}}$ & $207.3^{\mathrm{c}}$ & $19.6^{\mathrm{b}}$ & $4083.5^{\mathrm{b}}$ \\
\hline 5 & $39.64^{\mathrm{a}}$ & $1.58^{\mathrm{b}}$ & $189.5^{\mathrm{b}}$ & $16.9^{\mathrm{ab}}$ & $1.46^{\mathrm{a}}$ & $241.1^{\mathrm{b}}$ & $28.6^{\mathrm{a}}$ & $7147.1^{\mathrm{a}}$ \\
\hline 10 & $40.33^{\mathrm{a}}$ & $1.81^{\mathrm{a}}$ & $206.7^{\mathrm{a}}$ & $18.4^{\mathrm{a}}$ & $1.72^{\mathrm{a}}$ & $246.2^{\mathrm{a}}$ & $32.7^{\mathrm{a}}$ & $7924.5^{\mathrm{a}}$ \\
\hline
\end{tabular}

Means that have at least one common letter didn't show significant difference in $5 \%$ level

Table 4 Effect of triple superphosphate on the growth characteristics and grain yield in the Corn plants.

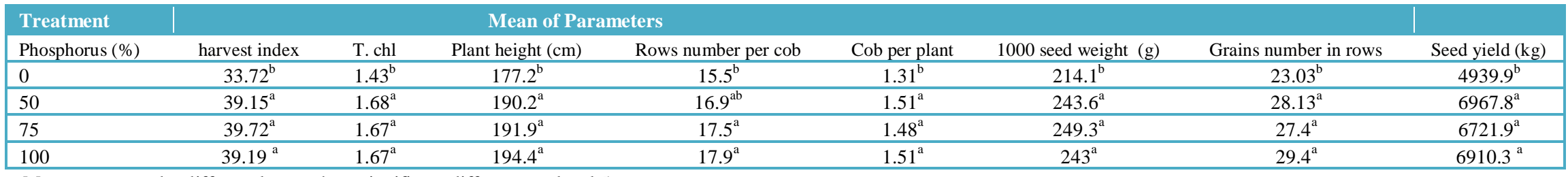

Means represent by different letters show significant difference at level 5\% 
Table-5 Effect of combined application of vermicompost and triple superphosphate on the various growth and yield parameters for the corn plants

\begin{tabular}{|c|c|c|c|c|c|c|c|c|c|}
\hline \multicolumn{3}{|c|}{ Treatment } & \multicolumn{5}{|c|}{ Mean of Parameters } & \multirow[b]{2}{*}{$\begin{array}{l}\text { Grains } \\
\text { number in } \\
\text { rows }\end{array}$} & \multirow[b]{2}{*}{$\begin{array}{l}\text { Seed } \\
\text { yield } \\
(\mathrm{kg})\end{array}$} \\
\hline $\begin{array}{l}\text { Vermicompost } \\
(\mathrm{t} / \mathrm{ha})\end{array}$ & $\begin{array}{c}\text { Phosphorus } \\
(\%)\end{array}$ & $\begin{array}{l}\text { harvest } \\
\text { index }\end{array}$ & T. chl & $\begin{array}{l}\text { plant } \\
\text { height } \\
(\mathrm{cm})\end{array}$ & $\begin{array}{c}\text { Rows number } \\
\text { per cob }\end{array}$ & $\begin{array}{l}\text { Cob } \\
\text { per } \\
\text { plant }\end{array}$ & $\begin{array}{c}1000 \text { seed } \\
\text { weight } \\
(\mathrm{g})\end{array}$ & & \\
\hline & 0 & $26.3^{\mathrm{c}}$ & $1.36^{\mathrm{c}}$ & $162.8^{\mathrm{c}}$ & $13.6^{\mathrm{C}}$ & $1.01^{\mathrm{d}}$ & $179.3^{\mathrm{a}}$ & $14.7^{\mathrm{e}}$ & $2590.8^{\mathrm{h}}$ \\
\hline & 50 & $36.24^{\mathrm{b}}$ & $1.45 \mathrm{~b}^{\mathrm{e}}$ & $168.3^{\mathrm{c}}$ & $14.8^{\mathrm{c}}$ & $1.14^{\mathrm{cd}}$ & $214.6^{\mathrm{d}}$ & $18.7^{\mathrm{d}}$ & $4382.3^{\mathrm{g}}$ \\
\hline \multirow[t]{4}{*}{0} & 75 & $36.38^{\mathrm{b}}$ & $1.48 \mathrm{~b}^{\mathrm{e}}$ & $171.4^{\text {be }}$ & $16.3^{\text {be }}$ & $1.26^{\mathrm{cd}}$ & $219.7^{\mathrm{d}}$ & $20.6^{\mathrm{cd}}$ & $4432.9^{\mathrm{eg}}$ \\
\hline & 100 & $36.53^{\mathrm{b}}$ & $1.49 b^{\mathrm{e}}$ & $173.9^{\text {be }}$ & $17.4^{\mathrm{b}}$ & $1.33^{\mathrm{c}}$ & $215.6^{\mathrm{d}}$ & $24.3^{\mathrm{c}}$ & $4927.9^{\mathrm{e}}$ \\
\hline & 0 & $36.43^{\mathrm{b}}$ & $1.41 b^{c}$ & $179.8^{\text {be }}$ & $15.9^{\text {be }}$ & $1.41^{\text {be }}$ & $226.7^{\mathrm{d}}$ & $24.7^{\mathrm{c}}$ & $5681.7^{\mathrm{d}}$ \\
\hline & 50 & $40.53^{\mathrm{a}}$ & $1.64^{\mathrm{b}}$ & $187.6^{\mathrm{b}}$ & $16.6^{\text {be }}$ & $1.44^{\text {be }}$ & $246.9^{c}$ & $28.9^{\mathrm{b}}$ & $7573.9^{c}$ \\
\hline \multirow[t]{4}{*}{5} & 75 & $41.37^{\mathrm{a}}$ & $1.62^{\mathrm{b}}$ & $193.8^{\mathrm{b}}$ & $17.7^{\mathrm{b}}$ & $1.48^{\text {be }}$ & $248.8^{\mathrm{c}}$ & $29.6^{\mathrm{b}}$ & $7689.3^{\mathrm{c}}$ \\
\hline & 100 & $40.24^{\mathrm{a}}$ & $1.65^{\mathrm{b}}$ & $196.9^{\mathrm{b}}$ & $17.6^{\mathrm{b}}$ & $1.52^{\mathrm{b}}$ & $241.7^{\mathrm{c}}$ & $31.4^{\mathrm{b}}$ & $7643.5^{\mathrm{c}}$ \\
\hline & 0 & $38.42^{\mathrm{b}}$ & $1.53^{\text {be }}$ & $189.1^{\mathrm{b}}$ & $16.9^{\text {be }}$ & $1.51^{\mathrm{b}}$ & $236.2^{\mathrm{c}}$ & $29.7^{\mathrm{b}}$ & $6547.3^{\mathrm{d}}$ \\
\hline & 50 & $40.69^{a}$ & $1.93^{\mathrm{a}}$ & $214.7^{\mathrm{a}}$ & $19.4^{\mathrm{a}}$ & $1.96^{\mathrm{a}}$ & $269.4^{\mathrm{b}}$ & $36.8^{\mathrm{a}}$ & $8947.3^{\mathrm{a}}$ \\
\hline \multirow[t]{2}{*}{10} & 75 & $41.4^{\mathrm{a}}$ & $1.91^{\mathrm{a}}$ & $210.7^{\mathrm{a}}$ & $18.6^{\mathrm{a}}$ & $1.71^{\mathrm{b}}$ & $279.6^{\mathrm{a}}$ & $31.9^{b}$ & $8043.7^{b}$ \\
\hline & 100 & $40.82^{\mathrm{a}}$ & $1.87^{\mathrm{a}}$ & $212.6^{\mathrm{a}}$ & $18.8^{\mathrm{a}}$ & $1.69^{\mathrm{b}}$ & $271.7^{b}$ & $32.6^{\mathrm{b}}$ & $8159.6^{b}$ \\
\hline
\end{tabular}

Means that have at least one common letter didn $\mathrm{t}$ show significant difference in $1 \%$ level

Increasing the vermicompost and phosphorus quantity applied increased the chlorophyll content of the corn plant but in case of phosphorus such improvement was not reported and all the selected percentage of the phosphorus are at par to each other and not showing any significant differences (Table 3 and 4). Mean comparison of the effect of these two factors interaction showed that chlorophyll content was the highest $(1.93 \mathrm{mg} / \mathrm{g})$ in $10 t /$ ha vermicompost $+50 \%$ phosphorus combination while it was the lowest in control without fertilization (Table 5).

\subsection{Fertilization and plant height}

Height of corn plant was also significantly affected by the application of vermicompost and phosphorus (Table 2). Mean comparison indicated that the plant height increased from $169.1 \mathrm{~cm}$ (control plants) to $206.7 \mathrm{~cm}$ in $10 \mathrm{t} / \mathrm{ha}$ by the application vermicompost (Table 3). Individual application of phosphorus is not showing significant difference at various selected level but it is significantly differ than the control. Results of the mean comparison of the effect of the two factors interaction (Table 5) showed similarity with the chlorophyll content and highest plant height $(214.7 \mathrm{~cm})$ was reported from the treatment containing combination of 10 ( $t /$ ha) vermicompost $\times 50 \%$ phosphorus (Table 5 ).

3.3 Impact of fertilization on harvest index and rows number per cob

Analysis of variance showed that vermicompost, phosphorus and two factors interaction significantly affected the harvest index and row number per cob (Table 2). Increasing the level of vermicompost and phosphorus either individually or in combination also increased the harvesting index and row number per cob in the maize plant (Table $3,4 \& 5$ ).

\subsection{Cob per plant}

A significant difference was reported in the number of cob per plant on the application of vermicompost and phosphorus $(\mathrm{p}<$ 0.05). Mean comparison indicated that the cob per plant increased from 1.18 (control) to 1.72 in $10 \mathrm{t} /$ ha vermicompost treatment (Table 3). Increasing in the applied phosphorus quantity also increased the rows number per cob (Table 4). Mean comparison of the effect of the two factors interaction showed that cob per plant was the highest in $10 \mathrm{t} / \mathrm{ha}$ vermicompost $+50 \%$ phosphorus $(1.96 \mathrm{~cm})$ and was the lowest (1.01) in control plants (Table 5).

\subsection{Effect of fertilization on seed weight}

Analysis of variance showed that vermicompost, phosphorus and two factors interaction significantly affected the weight of 1000 seed (Table 2). Results presented in table. 3 shows that 1000 seed weight in corn increased with the increase in phosphorus levels. Mean comparison of the effect of the two factors interaction showed that 1000 seed weight was the highest in $10 \mathrm{t} /$ ha vermicompost $\times 75 \%$ phosphorus (279.6 g) combination and the lowest (179.3 g) seed weight (for 1000 seeds) was reported in control plants without fertilization (Table 5).

\subsection{Number of seeds in a rows and seed yield}

Number of grain per row and final yield was also influenced by the application of fertilizers, results presented in table 3 shows that grains number in rows increased with the increase in phosphorus levels. Mean comparison of the effect of the two factors interaction showed that grains number in rows was highest $(36.8 \mathrm{seed} / \mathrm{row})$ in treatment containing combination 
of $10 \mathrm{t}$ / ha vermicompost $+50 \%$ phosphorus (Table 5). Similar types of results were reported for the final seed yield and analysis of variance showed that vermicompost, phosphorus and two factors interaction significantly affected the seed yield (Table 2). Increasing the quantity of phosphorus application also increased the seed yield in corn (Table 4).

Increasing the vermicompost quantity also promoted plant growth as well as growth of the cob webs by increasing the zinc and phosphorous like nutrients. Zinc enhances plant growth regulation whilst phosphorous promotes plant growth (Abbasi et al., 2009; Manyuchi et al., 2013a ; Manyuchi et al., 2013b). Increasing the level of phosphorous content in the soils also promoted plant growth, high resistance and quality of seed. Furthermore, it was well documented that increasing the application time of both the vermicompost and vermiwash also increased the soil copper, iron and phosphorous content (Manyuchi et al., 2013c; Nath \& Singh 2012). This increase in soil nutrient content promoted plant growth and chlorophyll production; hence boost the overall Zea mays growth. In addition, microbial activities was also reported higher in the soil treated by vermicompost and this higher microbial activity also affected the production of plant growth regulators such as cytokinins as well as humic acid which promote plant growth (Gopal et al., 2010; Manyuchi et al., 2013d)

\section{Conflict of interest}

Authors would hereby like to declare that there is no conflict of interests that could possibly arise.

\section{References}

Abbasi T, Gajalakshmi S, Abbasi SA (2009) Towards modeling and design of vermicomposting systems: Mechanisms of composting/vermicomposting and their implications. Indian Journal of Biotechnology 8: 177-182.

Adediran JA, Banjoko VA (2003) Comparative effectiveness of some compost fertilizer formulations for maize in Nigeria. Nigerian Journal of Soil Science 13: 42-48.

Anonymous (1979) Plantation in Baby corn. Even Thai National corn and sorghum reporting program, Bangkok Government of Thailand report.

Ansari AA, Sukhraj K (2010) Effect of vermiwash and vermicompost on soil parameters and productivity of okra (Abelmoschus esculentus) in Guyana. Pakistan Journal of Agricultural Resources 23: 137-142.

Fairhurst T, Lefroy R, Mutert E, Batjes N (1999) The importance, distribution and causes of phosphorus deficiency as a constraint to crop production in the tropics. Agroforestry Forum 9:2-8.

FAO (2007) Food and Agriculture Organization yearbook Volume 60.
Fashina AS, Olatunji KA, Alasiri KO (2002) Effects of different plant population and poultry manure on yield of Ugu (Telfairia occidentalis) in Lagos State, Nigeria. Proceedings of the annual Conference of Horticultural Society of Nigeria (HORTON), pp. 123-127.

Gerke J (1992) Orthophosphate and organic phosphate in the soil solution of four sandy soils in relation to $\mathrm{pH}$-evidence for humic-FE-(AL-) phosphate complexes. Communications in Soil Science and Plant Analysis 23: 601- 612. DOI:10.1080/00103629209368612

Gopal M, Gupta A, Palaniswami C, Dhanapal R, Thomas GV (2010) Coconut leaf vermiwash: a bio-liquid from coconut leaf vermicompost for improving the crop production capacities. Current Science 98: 1202-1210.

Jadia DC, Fulekar MH (2008) Vermicomposting of vegetable waste: A biophysicochemical process based on hydrooperating bioreactor. African Journal of Biotechnology 7: 3723-3730.

Jaliya MM, Falaki AM, Mahmud M, Sani YA (2008) Effects of sowing date and NPK fertilizer rate on yield and yield components of quality protein maize (Zea mays L.). ARPN Journal of Agricultural and Biological Science3:23-29.

Law-Ogbomo KE, Law-Ogbomo JE (2009) The Performance of Zea mays as Influenced by NPK Fertilizer Application. Notulae Scientia Biologicae 1: 59-62.

Magid J, Tiessen H, Condron LM (1996) Dynamics of organic phosphorus in soils under natural and agricultural ecosystems. In Piccolo $\mathrm{H}$ (Ed.) Humic substances in Terrestrial Ecosystems, Elsevier, Amsterdam, Pp. 429-66.

Manyuchi MM, Chitambwe T, Muredzi P, Kanhukamwe Q (2013c) Continuous Flow-through Vermireactor for Medium Scale Vermicomposting. Asian Journal of Engineering and Technology 1:5-9.

Manyuchi MM, Chitambwe T, Phiri A, Muredzi P, Kanhukamwe Q (2013a). Effect of Vermicompost, Vermiwash and Application Time on Soil Physicochemical Properties. International Journal of Chemical and Environmental Engineering 4: 216-220.

Manyuchi MM, Kadzungura L, Phiri A, Muredzi P (2013b) Effect of Vermicompost, Vermiwash and Application Time on Zea mays Growth. International Journal of Scientific Engineering and Technology 2: 638-641.

Manyuchi MM, Phiri A, Muredzi P, Chitambwe T (2013d), Comparison of Vermicompost and Vermiwash Bio Fertilizers from Vermicomposting Waste Corn Pulp. World Academy of Science, Engineering and Technology 7: 360-371. 
Nath G, Singh K (2012) Effect of vermiwash of different vermicomposts on the kharif crops.Journal of Central European Agriculture 13: 379-402. doi: 10.5513/JCEA01/13.2.1063.

Obi CO, Nnabude PC, Onucha E (2005) Effects of kitchen waste compost and tillage on soil chemical properties and yield of okra (Abelmoschus esculentus). Soil Science 15:69-76.

Palanichamy V, Mitra B, Reddy N, Katiyar M, Rajkumari RB, Ramalingam C, Arangantham (2011) Utilizing Food Waste by Vermicomposting, Extracting Vermiwash, Castings and Increasing Relative Growth of Plants. International Journal of Chemical and Analytical Science 2 : 1241-1246.

Predieri S, Dris R, Rapparini F (2004) Influence of growing conditions on yield and quality of cherry: II. Fruit quality. Food, Agriculture \& Environment 2: 307-309.
Saeed I, Abbasi MK, Kazim M (2001) Response of maize (Zea mays L.) to NP fertilization under agro-climatic condition of Rawalokol, Azad Jammu and Kaslim and Kashmir. Pakistan Journal of Biological Sciences 4: 949-952.

Steiner KG (1991) Overcoming soil fertility constraints to crop production in West Africa: Impart of traditional and improved cropping systems on soil fertility. In: Uzo Mokwunye A (Ed) Alleviating Soil Fertility Constraints to Increased Crop Production in West Africa, Kluwer Academic Publisher, Springer Netherlands pp. 69-91. doi:10.1007/978-94-0113224-4_7

Zibilske LM, Bradford JM, Smart JR (2002) Conservation tillage induced changes in organic carbon, total nitrogen and available phosphorus in a semi-arid alkaline subtropical soil. Soil and Tillage Research 66: 153-63. doi:10.1016/S01671987(02)00023-5. 